\title{
A literature review of mammalian research respective to the Akagera ecosystem in Rwanda
}

\author{
P. Sun ${ }^{1}$, J.D. Bariyanga ${ }^{1}$, T. Wronski ${ }^{2}$ \\ ${ }^{1}$ University of Rwanda, School of Science and Technology, Department of Biology, Huye, \\ Rwanda. \\ ${ }^{2}$ Liverpool John Moores University, School of Natural Sciences and Psychology, Faculty \\ of Science, James Parsons Building, Byrom Street, Liverpool, L3 3AF, UK, phone: \\ +44(0)151 2312563, email: t_wronski@gmx.de
}

\begin{abstract}
The Akagera NP (and the Mutara GR) in north-eastern Rwanda are considered part of the most complex and biodiversity rich savannah ecosystem in eastern Africa. Following the violent past of Rwanda, the park has recovered from civil war, poaching and overgrazing, counting today more than 12,000 large mammals. Since proclamation in 1934, a wealth of ecological research was carried in these protected areas. This literature review summarizes the available literature and puts it into a historical context, compiling more than 90 books, book chapters, and journal articles but also unpublished theses and reports respective to the ecology and conservation of mammals.
\end{abstract}

Key words: literature review, Akagera ecosystem, conservation history, mammals

Résumé Le Parc National de l'Akagera (et le Domaine de Chasse du Mutara) au Rwanda du nord-est sont considérés une partie de l'écosystème plus complexe et riche en biodiversités de la savane en Afrique orientale. Après le passé violent du Rwanda, le parc a récupéré de la guerre civile, chasse illégale et surpâturage, comptant aujourd'hui plus de 12.000 grands mammifères. Depuis la proclamation en 1934, une quantité de recherche écologique a été portée dedans ces zones protégées. Cette revue de littérature récapitule la littérature disponible et la met dans un contexte historique, rassemblant plus de 90 livres, chapitres de livre, et articles de journal mais également thèses non publiées et rapports respectifs à l'écologie et à la conservation des mammifères.

Mot clés: revue de littérature, écosystème de l'Akagera, histoire de la conservation, mammifère 


\section{Introduction}

Since Henry Morton Stanley came to find the source of the River Nile in 1876, the area between the Albertine Rift Valley (reaching as far east as the Byumba Escarpment) and the Lake Victoria forest belt is known as the Akagera ecosystem (sensu Kindt et al., 2014). Already Stanley remarked the extraordinary richness of wildlife in this area (Stanley, 1891; Akeley, 1950) and as early as 1934 the Belgian colonial government of Ruanda-Urundi declared the area west of the Akagera River a protected area - the Akagera National Park (NP). The Akagera NP (2,500 $\left.\mathrm{km}^{2}\right)$ and the adjacent former Mutara Game Reserve (GR; $300 \mathrm{~km}^{2}$ ) in north-eastern Rwanda, are considered part of the most complex savannah ecosystem in eastern Africa, combining wetlands and several savannah habitats (Kanyamibwa, 1998). The Mutara GR (formerly also called Mutara Hunting Reserve) was annexed by the local pastoralist community in 1971, and subsequently reduced from $855 \mathrm{~km}^{2}$ to $612 \mathrm{~km}^{2}$. In 1991, the Mutara GR was further reduced to its final size till it was eventually degazetted - together with the western parts of the Akagera NP-in 1997 (de Leyn, 1960). Until today about 50 mammal species have been reported for this area, and since the protected areas were proclaimed, a wealth of research has been carried out on the mammalian wildlife in this unique landscape. Until to date numerous books, book chapters and journal articles were published, but also several unpublished theses and reports are available. In recent years, after the country had recovered from civil war, ecological research in and around the modern Akagera NP has gained momentum again. Here we provide an overview on what literature on mammals is available, which will assist future researchers to easier access it.

\section{Methodology}

This review article intends to gather most (if not all) published and unpublished literature respective to mammalian species in the Akagera ecosystem of Rwanda and puts it into a historical context. To achieve this goal, we applied several search strategies such as computer based search in 'Google Scholar', applying a selection of key words relating to the Akagera ecosystem and the National Park. More important, we checked the reference sections of known publications and compilations to obtain further 
citations. These were searched again for unknown references, and so on. Last but not least, Jonathan Kingdon's Mammals of Africa (Kingdon et al., 2013) was systematically searched for any reference relating to Rwanda or the Akagera National Park. The review period extended over six months from November 2016 to April 2017.

\section{Chronological literature review}

In the early 1940s, a first mammal list for Rwanda (incl. Akagera NP) was published by Schouteden $(1943,1947)$. At that time herds of African buffalo (Syncerus caffer), bohor reedbuck (Redunca redunca wardi) and lions (Panthera leo) were observed as far west as Lake Muhazi near the Kayonza-Kagitumba road (Van den Berghe, 1942; Vienne et al., 1980; Vande weghe, 1990). First scientific studies on the mammalian community and the population structure of large ungulates in relation to vegetation and main predators were carried out in the 1940/50s by the Institut des Parcs Nationaux du Congo et du Rwanda-Urundi (Frechkop and Verheyen, 1944; Curry-Lindahl, 1961; Bourliere, 1965; Verschuren et al., 1965). At that time, large parts of the park were encroached by pastoralists and their cattle, until around 1960, when political instability affected Rwanda and many Rwandans were forced to exile (de Leyn, 1960).

In the 1970s and early 1980s, wildlife recovered and Akagera NP advanced to one of the most renowned protected areas in sub-Saharan Africa. First community conservation approaches were discussed (Ruwet, 1974), and first systematic ecological research was conducted inside the park, e.g., Spinage and Guinness (1971) studied the survival of trees in the absence of elephants (Loxodonta africana). From 1960 to 1975, Akagera NP had no elephant population, until about 50 elephants were translocated from Bugesera District in southern Rwanda (Monfort A. and Monfort N., 1977, 1979a; Haigh et al. 1979). Prior to their introduction into Akagera NP, Monfort A. and Monfort N. (1979b) studied the food intake and the energy balance of two young elephants inside a pre-release enclosure. Moreover, Monfort A. (1972) provided a preliminary record on the density, biomass and structure of wild ungulate populations, while Spinage (1969) and Spinage et al. (1973) carried out first wildlife counts and provided population estimates for the larger mammals in the park. Numerous studies were carried out on the ecology and social organisation of ungulates in the park (Monfort A., 1973; Monfort et 
al., 1973). Monfort A. (1974) studied the ecology of warthogs, Monfort A. and Monfort N. (1974) focused on the ecology of oribi (Ourebia ourebi), Monfort N. (1974a) worked on the social structure of impalas and Monfort N. (1974b, 1975), Froment (1980) and Monfort-Braham (1985) studied the social and spatial organisation of topi (Damaliscus korrigum jimela). Furthermore, Monfort A. and Monfort N. (1978) provided insights in the social structure and habitat utilisation of the park's zebra (Equus quagga) population, and Monfort N. $(1979,1980)$ conducted two detailed studies on the social organisation and the adaptions of African buffalo to the semi-arid environment in the Akagera ecosystem. Other ecological studies focused on the effects of fire and salinity on the ungulate community in Akagera NP and the Mutara GR (Spinage and Guinness, 1972; Minani, 1986). In the 1980s Akagera was one of the most visited national parks in Africa (Monfort A. and Monfort N., 1982), but also faced management problems and increased poaching (Monfort N., 1981). In contrast to what was known about elephants in the Akagera region, giraffes never occurred in the savannahs of eastern Rwanda (although they occurred in the Burigi region of north-western Tanzania; Rogers et al., 1977). In January 1986, six Masai giraffes (Giraffa camelopardalis tippelskirchi) were translocated from Lake Magadi in Kenya and released in the park (Vande weghe, 1990). During that period of relative political stability, more comprehensive species lists of mammals occurring in Rwanda were published by Monfort N. (1985), Verschuren (1987) and later up-dated by Monfort A. (1992), also including new records from Akagera NP.

In the late 1980s, research concentrated on the conservation status of the protected area and on changes in the vegetation structure due to increasing human impact (Verschuren, 1986, 1988). Resulting from those surveys Monfort N. (1988) published a first account on the conservation status of antelopes in the park. Subsequently, two internationally funded conservation projects were initiated in Akagera NP, attempting to establish the status of wildlife and to implement distinct conservation measures (Vande weghe and Dejace, 1991; Fourniret and De Schrevel, 1993; Fourniret, 1994; Chardonnet and East, 1995; Williams and Ntayombya, 1999).

Since 1990, Akagera NP has suffered from the successive effects of civil war, genocide and the invasion of returning refugees and their cattle. In the mid-1990s, when peace 
had returned, large areas of Akagera NP and the Mutara GR were occupied by pastoralists and their livestock with the consequence of a severe reduction of wildlife numbers (Chardonnet and East, 1995; East, 1999). In 1997, the Mutara GR (300 km²) and the northern and western sections of Akagera NP $\left(1,680 \mathrm{~km}^{2}\right)$ were degazetted. The total protected area was reduced from $2,800 \mathrm{~km}^{2}$ to only $1,120 \mathrm{~km}^{2}$. To determine the ecological viability of the new Akagera NP, the biodiversity of the reduced park and the degazetted area of the former park were assessed by Williams and Ntayombya (1999, 2001) as part of the Akagera Biodiversity Project. The reduction of protected area by $60 \%$ (one of the largest size reductions in modern African conservation history; Kanyamibwa, 1998; Bizoza and Madina, 2013) eliminated three important habitat types, i.e., the sub-humid savannah in the west, the Acacia kirkii gallery forest along the Akagera River in the north and the flood plains in the centre of the former National Park. This habitat loss had adverse effects on species using these habitats either for feeding (eland, Taurotragus oryx, warthog, Phacochoerus africanus; waterbuck, Kobus defassa and plains zebra), or for breeding (topi). By contrast, some vegetation communities such as the lakes and adjoining swamp systems are still well represented in the new park and provide important habitat for species such as sitatunga (Tragelaphus spekii; Beudels-Jamar et al., 1997) or hippos (Hippo potamus amphibius; Williams and Ntayombya, 1999). Wildlife populations in the degazetted parts of the former park were rapidly decimated due to vegetation changes caused by overgrazing with cattle, and uncontrolled hunting for meat and entertainment (mainly by military personal between 1990 and 1997). As a result of these adverse factors, a significant decline in the numbers of larger mammal species was observed, reducing the abundance of impala, buffalo, warthog, waterbuck, topi and oribi by about 75-80\% (Kanyamibwa, 1998; Plumptre et al., 2001; Schoene, 2003). Three species have undergone even more severe population declines, i.e. the bohor reedbuck, the roan antelope (Hippotragus equinus) and the black rhinoceros (Diceros bicornis). Before the political unrest of the 1990s, about 145 roan were reported from the former Akagera NP (Beudels et al., 1992), but declined to only 31 individuals in 1998 (Vande weghe and Dejace, 1991; Williams and Ntayombya, 1999, 2001). By 2013, the roan population had recovered to 83 individuals occupying an area of favourable habitat in the west-central part of the new Akagera NP (Macpherson, 2013). Today, the roan is considered the most threatened antelope species 
in the park and its conservation must have priority since the Akagera population is the last in a corridor once connecting the southern populations to those of East and West Africa (Vaz Pinto et al., 2016). Originally, the black rhinoceros did not occur inside the protected area but was introduced in 1957 (Haezaert, 1969). After a significant population increase to more than 50 individuals, the political turmoil of the $1990 \mathrm{~s}$ resulted in a sharp decline of the population until it was reported extinct in Akagera NP in 1994 (Vande weghe, 1990). The last rhino in Rwanda was encountered south of the new Akagera NP in 2007 (Mwai, 2017). Between February and March 2017, a founder population of Eastern black rhinos were captured on the Thaba Tholo Game Ranch in South Africa and translocated to Rwanda where they were reintroduced into Akagera NP in May 2017 (African Parks, 2017).

The political instability during (and after) the civil war had also implications on the law enforcement in the new Akagera NP, leading to a lack of protection activities, and hence to further loss of wildlife (Kanyamibwa, 1998; Plumptre et al., 2001). After stability had resumed, some studies monitored the persistence and/or recovery of ungulates in the modern Akagera NP and adjacent areas (i.e., the former Mutara GR and degazetted parts of the former Akagera NP). While Lamprey (2002), conducting an aerial survey, reported on depleted numbers of larger ungulates, Apio and Wronski (2011) carried out a road strip count revealing a recovery, at least for impala and topi. Even for the degazetted parts, outside the yet unfence modern Akagera NP, Gatare (2011) reported good numbers of impala, zebra, waterbuck and oribi. These promising results were supported by aerial surveys of Viljoen (2010) and Macpherson (2013). In the same year, Gatali (2013) estimated the population size of larger mammals in Akagera NP and reported on positive effects of the recovering vegetation on the ungulate fauna. Recently, Apio et al. (2015b) estimated the abundance of bushbuck (Tragelaphus sylvaticus) and common duiker (Sylvicapra grimmia) in the degraded parts of the former protected areas, using local ecological knowledge. Simultaneously, Hirwa and Nsengimana (2015) estimated the persistence of other wildlife species (including small carnivores and lagomorphs) in the same area applying the same technic. Wronski et al. (2015) investigated an isolated, surviving population of impalas in the Kazaza Sector, a part of the Mutara GR that was lost for conservation as early as 1970. 
From 2010 to 2015, Apio et al. (2017) conducted further road strip counts to evaluate the population development of ungulates in the new Akagera NP. The study provided surprising results: numbers of impala, zebra and waterbuck seem to have reached the carrying capacity of the new Akagera NP (Goodman, 2003), and are in decline again. Resulting from road strip counts, Apio et al. (2015a) also provided a detailed up-date on the positive population development of African buffalo in the park. Given this and the small size of the modern Akagera NP-especially after the park was electro-fenced in 2013 (RDB, 2013) - the necessity for continuous monitoring of ungulate populations inside and outside the park is imperative. Most recently, Bariyanga et al. (2016) published a study on the population development of larger ungulates in the Uruhita Valley (in the centre of the former Akagera NP) before and after the new fence was closed. The authors report on the effectiveness of fencing and the helicopter based game drive, herding wildlife into the new park. Fencing national parks has become a widespread practice to reduce human-wildlife conflicts but fences also prevent the dispersal of wildlife, leading to overstocking especially if predatory species have gone extinct. African wild dogs (Lycaon pictus) are considered extinct in Akagera NP (de Leyn, 1962), lions (Panthera leo) have not been reported for at least 15 years (Lamprey, 2002) but were recently reintroduced to the new park (Hall, 2015; Toovey, 2015), while spotted hyenas (Crocuta crocuta) and leopards (Panthera pardus) persisted inside the new park (Macpherson, 2013), but also outside (e.g. Muvumba riverine; Bariyanga, unpubl. data).

Compared to what is known about the larger game species and their predators, surprisingly few studies have focused on primates or small carnivores. Lejeune (1981, 1984, 1985, 1986) studied the ecology and social organisation of olive baboon (Papio anubis) in Akagera NP, and Lejeune, (1989a, b, 1990) and Lejeune and Frank (1990) reported on the ecology and behaviour of spotted-necked otter (Lutra maculicollis) and its impact on commercial fishing in Lake Muhazi. For rodents (Missone, 1965) and bats (Verschuren, 1965; Baeten et al., 1984) some information is available from Akagera NP, while for insectivores barely a species list was compiled (Hutterer et al., 1987). Only recently, the persistence of southern tree hyrax (Dendrohyrax arboreus) was confirmed for the Muvumba riverine forest (de Jong and Butynski, 2016), a strip of natural riparian Acacia kirkii woodland that marked once the border of the Mutara GR 
to the West. This still intact woodland continues to harbour some wildlife but is under severe pressure from an ever growing human population (ACNR, 2011; Tuyizere, 2015).

\section{Discussion and conclusion}

This literature review attempts to provide a comprehensive collection of published and unpublished literature respective to the Akagera ecosystem in Rwanda. However, while the published record is considered complete, there might be the chance that some unpublished reports and thesis remain undetected by our literature search. This may particularly apply to studies that were carried out by the National University of Rwanda (NUR; Butare) before 1994. It would be therefore beneficial to search the archives and libraries of NUR in order to further complete this bibliography. Nevertheless, this literature review provides an overview on what literature on mammalian wildlife is known from the region, which will assist future researchers to easier access it and to consider those studies in their future works. The extraordinary habitat diversity including forest fringed lakes, papyrus swamps, savannah plains and rolling highlands combine to make Akagera one of the most scenic protected areas in Africa. Akagera still has exceptional levels of biodiversity and forms the largest protected wetland in central Africa. The considerable improvement in the management and law enforcement of the new Akagera NP makes it an important role model for successful conservation and wildlife regeneration. This literature review is therefore also addressed to encourage future research to study the positive and adverse effects of modern conservation management in and around Akagera NP.

\section{References}

1. Akeley, M. L. J. (1950). Congo Eden. Dodd, Mead \& Co, New York, USA.

2. ACNR, Association pour la Conservation de la Nature au Rwanda (2011). Muvumba Galery Forest Conservation Project, Nyagatare District, Eastern Province, Rwanda. Technical report, IUCN/CARPE, Kigali, Rwanda.

3. African Parks (2017). Rhinos return to Rwanda [Press release May 22nd \& June 7th 2017]. Retrieved from https://www.rhinomove.org/about/. 
4. Apio, A. \& Wronski, T. (2011). A rough population estimate of large ungulates in the Akagera National Park, Rwanda. Gnusletter 29, 18-20.

5. Apio, A.; Gruner, J. \& Wronski, T. (2015a). Status of buffalo in Akagera National Park. Gnusletter Special Issue-African Buffalo 1, 27-29.

6. Apio, A.; Umuntunundi, P.; Lerp, H.; Bierbach, D.; Plath, M. \& Wronski, T. (2015b). Persistence of two small antelope species in the degraded Mutara Rangelands (Akagera ecosystem) based on pastoralists' and farmers' perceptions. Hum. Ecol. 43, 613-620.

7. Apio, A.; Plath, M. \& Wronski, T. (2017). Recovery of ungulate populations in the post-civil war Akagera National Park, Rwanda. J. East Afr. Nat. Hist. Soc. 104, 127141.

8. Baeten, B.; Van Cakenberghe, V. \& De Vree, F. (1984). An annotated inventory of a collection of bats from Rwanda (Chiroptera). Rev. Zool. Afr. 98, 183-196.

9. Bariyanga, J. D.; Wronski, T.; Plath, M. \& Apio, A. (2016). Effectiveness of electro-fencing for restricting the ranging behavior of wildlife: a case study in the degazetted parts of Akagera National Park. Afr. Zool. 51, 183-191.

10. Beudels, R. C.; Durant, S.M. \& Harwood, J. (1992). Assessing the risks of extinction for local populations of roan antelope Hippotragus equinus. Biol. Conserv. 61, 107-116.

11. Beudels-Jamar, R.C.; Devillers, P. \& Harwood, J. (1997). Estimating the size of the sitatunga (Tragelaphus spekii) in the Parc National de l'Akagera, Rwanda. J. Afr. Zool. $111,345-354$.

12. Bourlière, F. (1965). Densities and biomasses of some ungulate populations in eastern Congo and Rwanda, with notes on population structure and lion/ungulate ratios. Zool. Afr. 1, 199-207.

13. Curry-Lindahl, K. (1961). Exploration du parc national Albert et du parc national de la Kagera II. Mission K. Curry-Lindahl (1951-1952, 1958-1959). Institut des Parcs Nationaux du Congo et du Rwanda, Bruxelles, Belge.

14. Chardonet, P. \& East, R. (1995). Rwanda: Akagera National Park. In: Antelope Survey Update No. 1. (Ed. R. East), IUCN/SSC Antelope Specialist Group, Gland, Switzerland. pp. 21-23.

15. De Leyn, G. (1960). Le Domaine de Chasse du Mutura. Usambura 1, 1-12.

16. de Leyn, G. (1962). Contribution à la connaissance des lycaons au Pare National de la Kagera. Institut des Parcs Nationaux du Congo et du Rwanda, Bruxelles, Belge. 
17. De Jong, Y.A. \& Butynski, T.M. (2016). Hyraxes (Hyracoidea) [photographic map]. Eastern Africa Primate Diversity and Conservation Program, Nanyuki, Kenya. Retrieved from http://www.wildsolutions.nl/photomaps/hyrax/.

18. East, R. (1999). African Antelope Database 1998. IUCN/SSC Antelope Specialist Group, Gland, Switzerland.

19. Fourniret, Y. (1994). Recensement de la faune du Parc National de l'Akagera et du Domaine de chasse du Mutara (Rwanda). Période de Janvier 1993 à Mars 1994. Unpublished report, C.C.E.-O.R.T.P.N.-C.I.F.C.D., Kigali, Rwanda.

20. Fourniret, Y. \& de Schreve, N. (1993). Rapport de dénombrement de la grande faune du Parc National de l'Akagera (Rwanda). Projet de Sauvegarde et de Maintenance du Patrimoine Ecologique du Pare National de l'Akagera. Unpublished report, C.C.E.-O.R.T.P.N.-C.I.F.C.D., Kigali, Rwanda.

21. Frechkop, S. \& Verheyen, R. (1944). Mammifères. Exploration du Parc National de la Kagera: mission S. Frechkop (1938). Institut des Parcs Nationaux du Congo Belge, Série 2, Fascicule 2, 1-57.

22. Froment, J. M. (1980). Présentation du topi au Mutara pendant la période des naissances. Parc National de l'Akagera. Thèse Licence Sociale Zoologique Université de Liège, Belge.

23. Gatali, G. (2013). Herbivory and Biodiversity Conservation of the Savannah Habitats in Akagera National Park, Rwanda. PhD thesis, University of Gothenburg, Gothenburg, Sweden.

24. Gatare, R. (2011). Estimating abundance and densities of wild ungulate populations and cattle in the Uhurita Valley, former Akagera National Park. BSc thesis, University of Rwanda, Nyagatare Campus, Rwanda.

25. Goodman, P. S. (2003). Large herbivore carrying capacity estimate for Akagera National Park with provisional management recommendations. Unpublished Report, Gesellschaft für Technische Zusammenarbeit (GTZ), Kigali, Rwanda.

26. Haezaert, J. (1969). The Black Rhino is brought back to Rwanda. Oryx 5, 96-99.

27. Haigh, J. C.; Parker, S. C.; Parkinson, O. A. \& Archer, A. L. (1979). An elephant extermination. Environ. Conserv. 6, 306-310.

28. Hall, S. (2015). The king of the jungle is back. Rwanda welcomes lions at Akagera National Park after 21 years' absence. The Eye Magzine July-September 2015, 32-33.

29. Hirwa, M. R. M. \& Nsengimana, J. B. (2015). Estimating the persistence of wildlife species in the degraded Mutara Rangelands (Akagera ecosystem) based on pastoralists' and farmers perceptions. BSc thesis, University of Rwanda, Nyagatare Campus, Rwanda. 
30. Hutterer, R.; Van der Straeten, E. \& Verheyen, W. N. (1987). A checklist of the shrews of Rwanda and biogeographical considerations on African Soricidae. Bonn. zool. Beitr. 38, 155-172.

31. Kanyamibwa, S. (1998). Impact of war on conservation: Rwandan environment and wildlife in agony. Biodivers. Conserv. 7, 1399-1406.

32. Kindt, R.; van Breugel, P.; Lillesø, J.-P. B.; Minani, V.; Ruffo, C. K.; Gapusi, J.; Jamnadass, R. \& Graudal, L. (2014). Atlas and tree species composition for Rwanda. Potential natural vegetation of eastern Africa (Ethiopia, Kenya, Malawi, Rwanda, Tanzania, Uganda and Zambia), vol 9. Department of Geosciences and Natural Resource Management, University of Copenhagen, Copenhagen.

33. Kingdon, J.; Happold, D.; Butynski, T. M.; Hoffmann, M.; Happold, M. \& Kalina, J. (2013). The Mammals of Africa Vol. 1-6., Bloomsbury, London, UK, pp. 3,500.

34. Lamprey, R. H. (2002). Akagera-Mutara Aerial Survey, Rwanda. Unpublished Report, Gesellschaft für Technische Zusammenarbeit (GTZ), Kigali, Rwanda.

35. Lejeune, A. (1981). Écologie et structures sociales des babouins (Papio anubis) au Pare National de l'Akagera - Rwanda. Cahiers d'Ethologie Appliquée 1, 205-244.

36. Lejeune, A. (1984). La socialisation d'un jeune babouin orphelin Papio anubis réintroduit dans une troupe sauvage au parc de l'Akagera (Rwanda). Cahiers d'Ethologie Appliquée 4, 247-260.

37. Lejeune, A. (1985). Contribution a l'étude des variations écologique et sociales des babouins. Eco-ethologique d'une troup de Paplo anubis au Parc National de I' Akagera. $\mathrm{PhD}$ thesis, University of Liège, Belgium.

38. Lejeune, A. (1986). Contribution a l'étude des variations écologique et sociales des babouins : eco-éthologie d'un troupe de Papio anubis (Fischer, 1829). Exploration du Parc National de la Kagera. Institut des Parcs Nationaux du Congo et du Rwanda, Série 2, Fascicule 1, pp. 184.

39. Lejeune, A. (1989a). Les loutres, Lutra (Hydrictis) maculicollis et la pêche artisanale au Lac Muhazi (Rwanda). Rev. Zool. Afr. 103, 216-223.

40. Lejeune, A. (1989b). Ethologie de la loutre (Lutra maculicollis) au Lac Muhazi, Rwanda. Mammalia 53, 191-202.

41. Lejeune, A. (1990). Ecologie alimentaire de la loutre (Lutra maculicollis) au Lac Muhazi, Rwanda. Mammalia 54, 33-45.

42. Lejeune, A. \& Frank, V. (1990). Distribution of Lutra maculicollis in Rwanda: ecological constraints. IUCN Otter Specialist Group Bulletin 5, 8-16. 
43. Macpherson, D. (2013). Report on an Aerial Census of Akagera National Park, Rwanda - August 2013. Unpublished Report, CLUNY and Rwanda Development Board (RDB), Kigali, Rwanda.

44. Minani, F. (1986). Terres salines et grands ongulés du Pace National de l'Akagera. Importance biologique. Thèse Licence Sociale Zoologique, Université de Butare, Rwanda.

45. Missone, X. (1965). Rongeurs. Exploration du Pare National de la Kagera. Institut des Parcs Nationaux du Congo et du Rwanda, Série 2, Fascicule 1(3), 77-118.

46. Monfort, A. (1972). Densités, biomasses et structures des populations d'ongulés sauvages au Parc de l'Akagera (Rwanda). Rev. Ecol. Terre Vie 26, 216-256.

47. Monfort, A. (1973). Etude des préférences écologique de quelques ongulés du Rwanda Oriental. Densités, biomasses et productivités des grands ongulés du Parc National de I' Akagera. Fondation de l'Université de Liège pour les Recherches Scientifiques en Afrique Centrale (FULREAC), Liège, Belge.

48. Monfort, A. (1974). Quelques aspects de la biologie des phacochères au Parc National de l'Akagera. Mammalia 38, 177-200.

49. Monfort, A. (1992). Première liste commente ce des mammifères du Rwanda. J. Afr. Zool. 106, 141-151.

50. Monfort, A. \& Monfort, N. (1974). Notes sur l'écologie et le comportement des oribis. Rev. Ecol. Terre Vie 28, 169-208.

51. Monfort, A. \& Monfort, N. (1977). L'opération "éléphant" au Rwanda. Structure de la population du Bugesera et transfère de Jeune du Parc National de l'Akagera. Rev. Ecol. Terre Vie 31, 355-384.

52. Monfort, A. \& Monfort, N. (1978). Structure et répartition des populations de zebras au Parc National de l'Akagera, Rwanda. Mammalia 42, 316-322.

53. Monfort, A. \& Monfort, N. (1979a). Acclimatation et régime des jeunes éléphants introduits au Parc National de l'Akagera. Rev. Ecol. Terre Vie 33, 27-48.

54. Monfort, A. \& Monfort, N. (1979b). Rendement d'assimilation et bilan énergétique chez les éléphanteaux d'Afrique (Loxodonta africana Blumenbach). Mammalia 43, 543-557.

55. Monfort, A. \& Monfort, N. (1982). Akagera, Rwanda's biggest Park. Swara 5, 3133.

56. Monfort, A.; Monfort, N. \& Ruwet, J. C. (1973). Eco-éthologie des ongulés au Parc National de l'Akagera (Rwanda). Ann. Soc. R. Zool. Belg. 103, 177-208. 
57. Monfort, N. (1974a). Contribution à l'étude des structures sociales et du comportement des ongulés du Parc National de l'Akagera: l'impala. Fondation de l'Université de Liège pour les Recherches Scientifiques en Afrique Centrale (FULREAC), Liège, Belge.

58. Monfort, N. (1974b). Contribution A l'étude des structures sociales et du comportement des ongulés du Pare National de l'Akagera: le topi. Fondation de l'Université de Liège pour les Recherches Scientifiques en Afrique Centrale (FULREAC), Liège, Belge.

59. Monfort, N. (1975). Variation dans la structure sociale du topi du Parc National de l'Akagera, Rwanda. Z. Tierpsychol. 39, 332-364.

60. Monfort, N. (1979). Etude des populations de buffles Syncerus caffer (Sparrman) du Parc National de l'Akagera (Rwanda) I. Répartition spatiale et distribution. Z. Tierpsychol. 44, 111-127.

61. Monfort, N. (1980). Etude des populations de buffles Syncerus caffer (Sparrman) du Parc National de l'Akagera (Rwanda) II. Organisation et adaptation au milieu. Z. Tierpsychol. 45, 173-188.

62. Monfort, N. (1981). Problèmes de conservation et de gestion au Parc National de l' Akagera (Rwanda). La décennie 1968-78. Cah. Ethol. Appl. 1, 81-104.

63. Monfort, N. (1985). Les Mammiferes du Rwanda: Inyamaswa Zonsa Zo Mu Rwanda. Rotary Club of Kigali, Kigali, Rwanda.

64. Monfort, N. (1988). Rwanda. In: Antelopes Global Survey and Regional Action Plans. Part 1. East and Northeast Africa. (Ed. R. East), IUCN/SSG Antelope Specialist Group, Gland, Switzerland. pp. 66-68.

65. Monfort-Braham, N. (1985). Variations dans le structure sociale du topi, Damaliscus korrigum Ogilby, au Parc National de l'Akagera, Rwanda. Z. Tierpsychol. 39, 332-364.

66. Mwai, C. (2017). Rhinos back in Rwanda; 10 relocated to Akagera National Park. New Times June 26th 2017, Kigali, Rwanda.

67. Plumptre, A. J.; Masozera, M. \& Vedder, A. (2001). The impact of civil war on the conservation of protected areas in Rwanda. Wildlife Conservation Society (WCS), Biodiversity Support Program, Washington, DC.

68. RDB, Rwanda Development Board (2013). The electrical fence launched to counter the Akagera Park human-wildlife conflict. [Press release, 9 August 2013], Retrieved from

www.rdb.rw/de/home/newsdetails/article/the-electrical-fence-launched-to-counter-the-a kagera-park-human-wildlife-conflict.html. 
69. Rogers, W. A.; Ludanga R. I. \& Desuzo, H. P. (1977). Biharamulo, Burigi and Rubondo Game Reserves. Tanzan. Notes Rec. 81/82, 99-124.

70. Ruwet, J. C. (1974). La conservation du Parc National de l'Akagera et le développement de la région voisine (Rwanda). Zoologie et Assistance Technique. Fondation de l'Université de Liège pour les Recherches Scientifiques en Afrique Centrale (FULREAC), Liège, Belge. pp. 336-353.

71. Schoene, C. (2003). Rwanda, conservation in a haunted country. Unpublished Report, Projet de Protection des Réssources Naturelles (GTZ-PRORENA-AKAGERA), Gesellschaft für Technische Zusammenarbeit (GTZ), Kigali, Rwanda.

72. Schouteden, H. (1943). Catalogue des mammifères du Congo Belge et du Rwanda-Urundi. Rev. Zool. Bot. Afr. 37, 102-125.

73. Schouteden, H. (1947). De Zoogdieren van Belgisch Congo en van Ruanda-Urundi. Ann. Mus. Congo Belge, C. Zool. 2, 1-576.

74. Spinage, C. A. (1969). Les parcs nationaux du Rwanda: rapport écologique. Esquisse de l'écologie du Pare National de l'Akagera et du Domaine de Chasse du Mutara. Foreign and Commonwealth Office, London, UK.

75. Spinage, C. A. (1969). Outline of the Ecology of the Akagera National Park and the Mutara Hunting Reserve. Unpublished report, Rwanda National Parks, Part I. Ministry of Overseas Development, London, UK.

76. Spinage, C. A. \& Guinness, F. E. (1971). Tree survival in the absence of elephants in the Akagera National Park, Rwanda. J. Appl. Ecol. 8, 711-716.

77. Spinage, C. A. \& Guinness F. E. (1972). Effects of fire in the Akagera National Park and Mutara Hunting Reserve, Rwanda. Rev. Zool. Bot. Afr. 3, 302-336.

78. Spinage, C. A.; Guiness, F. E.; Eltringham, S. K. \& Woodford, M. H. (1972). Estimation of large mammal numbers in the Akagera NP and Mutara Hunting Reserve, Rwanda. Rev. Ecol. Terre Vie 26, 561-570.

79. Stanley, H. (1891). In Darkest Africa. Charles Scribner's Sons, New York.

80. Toovey, D. (2015). The king and queen of the jungle are back. Inzozi September-November 2015, 52-58.

81. Tuyizere, A. P. (2015). Identification and quantification of 'ten meter' rule violations along the Muvumba riverine forest, Nyagatare District, Rwanda. BSc thesis, University of Rwanda (Nyagatare Campus).

82. Van den Berghe, L. (1942). Exploration du Parc National Albert (Zaire) et du Parc National de la Kagera (Rwanda): mission L. Van den Berghe (1936). Institut des Parcs Nationaux du Congo Belge, Série 2, Fascicule 2, 1-57. 
83. Vande weghe, J. P. (1990). Akagera, Land of Water, Grass and Fire. Lannoo Printers and Publishers, Brussels, Belgium.

84. Vande weghe, J. P. \& Dejace, P. (1991). Rapport scientifique du Project 3747 du Fonds Mondial pour la Nature (WWF Belgique) au Parc National de l'Akagera et au Domaine de Chasse du Mutara, Rwanda. Vol I: Etude de l'écosystème de savanes. Unpublished report, WWF Belgium, Brussels.

85. Vande weghe, J. P.; Beudels, R. C.; Dejace, P.; Kalpers, J. \& Leroy, J. J. (1987). La conservation du Parc National de l'Akagera. Rapport préliminaire. WWF Belgium, Brussels.

86. Vaz Pinto, P.; Beja, P.; Ferrand, N. \& Godinho, R. (2016). Hybridazation following population collapse in a critically endangered antelope. Sci. Rep. 6, 18788. doi: 10.1038/srep18788.

87. Verschuren, J. (1965). Chiroptères. Exploration du Pare National de la Kagera. Institute des Parc Nationaux du Congo et du Rwanda, Série 2, Fascicule 1(2), 67-76.

88. Verschuren, J. (1986). Le Parc National de l'Akagera, au Rwanda, un des dix premiers parcs d'Afrique. Bull. Soc. R. Zool. Anvers 51, 13-19.

89. Verschuren, J. (1987). Liste commentée des Mammifères des Pares Nationaux du Zaire, du Rwanda et du Burundi. Bull. Inst. Roy. Sci. Nat. Belgique, Biol. 67, 17-39.

90. Verschuren, J. (1988). Notes sur l'évolution des habitats et de la grande faune depuis 1948. Exploration du Parc National de la Kagera. Institute des Parc Nationaux du Congo et du Rwanda, Série 2, Fascicule 2, 1-61.

91. Verschuren, J., Misonne, X. \& Lejeune, A. (1965). Contribution à l'écologie des grands mammifères. Exploration du Parc National de la Kagera. Institute des Parc Nationaux du Congo et du Rwanda, Série 2, Fascicule 1(1), 1-126.

92. Vienne, G.; Vienne, G. \& Lacombe, A. (1980). Akagera: des lions du Nil aux gorilles des monts de la lune. Flammarion, Paris, France.

93. Viljoen, P. (2010). Akagera National Park, Rwanda, Aerial Wildlife Survey, August 2010. Unpublished report, African Parks, Akagera NP, Rwanda.

94. Williams, S. D. \& Ntayombya, P. (1999). Akagera: An assessment of the biodiversity and conservation needs. Unpublished report, Zoological Society of London, UK and Ministry of Agriculture, Livestock, Environment and Rural Development, Rwanda.

95. Williams, S. D. \& Ntayombya, P. (2001). Rwanda: Akagera National Park. In: Antelope Survey Update 8 (Ed. R. East), IUCN/SSC Antelope Specialist Group, Gland, Switzerland. pp. 46-51. 
96. Wronski, T.; Bariyanga, J. D.; Apio, A. \& Plath, M. (2015). Interactions between wildlife, humans and cattle: activity patterns of a remnant population of impala on the degraded Mutara Rangelands, Rwanda. Rangeland J. 37, 357-365. 